\title{
PERANCANGAN E-KATALOG OBJEK WISATA MAMMINASATA
}

\author{
Alifya NFH ${ }^{1}$, Edi Suhardi Rahman ${ }^{2}$ \\ ${ }^{1}$ Pendidikan Teknik Informatika dan Komputer, Universitas Negeri Makassar \\ alifya.nfh@unm.ac.id \\ ${ }^{2}$ Pendidikan Teknik Elektro, Universitas Negeri Makassar \\ edisuhardi@unm.ac.id
}

\begin{abstract}
ABSTRAK
Promosi di media massa berupa pamflet dan majalah telah banyak dilakukan oleh pemerintah. Metode promosi tersebut belum mampu membantu masyarakat dalam malakukan visualisasi tempat dan lingkungan sekitar objek wisata. Media promosi obyek wisata berbasis E- Katalog sangat dibutuhkan guna mengatasi masalah-masalah tersebut. Penelitian ini bertujuan untuk menghasilkan sebuah e-katalog pada objek wisata "mamminasata" sebagai solusi untuk melakukan promosi wisata dalam skala besar oleh pemerintah. Metode penelitian yang digunakan adalah penelitaian Research and Development (R\&D) dengan masa penelitian enam bulan. Melalui aplikasi ini diharapkan (1) Masyarakat luas mampu mengetahui obyek wisata yang ada pada wilayah "mamminasata", (2) Pemerintah kabupaten mampu melakukan promosi dengan jaringan informasi melalui e-kalatolg. Hasil penelitaian yang diperoleh menunjukkan bahwa ekatalog yang telah dirancang siap untuk digunakan berdasarkan hasil validasi produk dan uji coba.
\end{abstract}

Kata Kunci: Promosi, E-Katalog, Mamminasata

\section{MAMMINASATA TOURISM OBJECT E-CATALOG DESIGN}

\begin{abstract}
Promotions in the mass media in the form of pamphlets and magazines have been widely carried out by the government. The promotion method has not been able to help the community in visualizing places and the environment around tourist objects. Media promotion of tourism objects based on E-Catalog is needed to overcome these problems. This study aims to produce an e-catalog on the "mamminasata" tourist attraction as a solution to carry out tourism promotion on a large scale by the government. The research method used is Research and Development $(R \& D)$ research with a research period of six months. Through this application, it is hoped that (1) the public will be able to find out about tourism objects in the "mamminasata" area, (2) the district government will be able to carry out promotions with information networks through e-kalatolg. The results obtained indicate that the e-catalog that has been designed is ready to be used based on the results of product validation and trials.
\end{abstract}

Keyword: Promotion, E-Catalog, Mamminasata 


\section{PENDAHULUAN}

Berkembangnya teknologi informasi yang demikian pesat di millennial sekarang ini sudah mencapai taraf sebagai kebutuhan, sehingga semua lapisan masyarakat tergerak untuk maju dan menggunakannya. Komputer dan smartphone merupakan contoh dari teknologi informasi yang digunakan hampir disetiap kegiatan masyarakat. Penggunaan teknologi informasi dapat mempermudah masyarakat dalam memperoleh sebuah informasi, ini juga berlalu untuk objek wisata.

Kota Metropolitan "Mamminasata" adalah mega project kota modern yang menggabungkan 4 daerah utama yaitu Makassar, Maros, Gowa dan Takalar. Kawasan Perkotaan Mamminasata mencakup 46 kecamatan dan memiliki banyak objek wisata. Obyek wisata yang ada Kota Makassar adalah pantai losari, benteng routerdam, benteng sumba opu, wahana permainan air bugis water park, pulau lae-lae, pulau samalona dan pulau kodingareng keke.

Selanjutnya objek wisata yang menjadi primadona wisatawan di Kabupaten Maros adalah air terjun Bantimurung dimana selain air terjun wisatawan juga dapat menikmati fasilitas fasilitas lain seperti : wisma dan penginapan, restoran, kolam renang dan water boom dan toko cinderamata. Selain fasilitas-fasilitas yang menarik wisatawan juga dapat menikmati keindahan Gua Batu dan beraneka ragam jenis kupu-kupu. Contoh objek wisata lainnya yang terdapat di Kabupaten Maros adalah Hutan Karst Rammang-Rammang, Goa Pattunuang, taman bersejarah Leang-Leang, Taman Safari Pucak dan Pantai Kuri.

Kabupaten gowa memiliki obeyek wisata berupa wisata kebun, dimana tempat wisata ini cocok untuk menjadi tempat wisata untuk keluarga. Selain wisata kebun ada juga Gowa Discovery Park, yang menyediakan wahana bermain air, dan, kebun binatang. Malino juga menjadi salah satu objek wisata yang paling populer yang berada di Kabupaten Gowa. Pantai galesong, pantai tope jawa, pantai punnaga dan pantai putondo merupakan objek wisata yang ada di Kabupaten Takalar.

Keunikan setiap objek wisata yang disertai dengan sarana prasarana yang mendukung dapat menarik minat wisatawan baik lokal maupun macanegara sehingga menjadi pundi-pundi sumber pemasukkan daerah yang tinggi [1].

Informasi yang minim mengenai sebuah objek wisata atau terlalu banyaknya informasi bisa membingungkan wisatawan dalam dalam menemukan daerah wisata tersebut. Selain itu di informasi dari mulut ke mulut juga dapat membuat wisatawan kecewa karena tidak sesuai dengan keadaan di objek wisata tersebut. Masalah-masalah ini terjadi akibat keterbatasan dalam mempromosikan obyek wisata.

Penggunaan peta konvensional dalam menemukan objek wisata masih menjadi pilihan masyarakat, namun penggunaan peta konvensional tidak dapat membantu wisatawan dalam menentukan rute terdekat. Peta konvensional juga tidak dapat mengefisienkan jalur wisata yang akan dikunjungi jika ingin mengunjungi beberapa objek wisata yang berdekatan.

Promosi di media massa berupa pamflet dan majalah telah banyak dilakukan oleh pemerintah. Metode promosi tersebut belum mampu membantu masyarakat dalam mengvisualisasi tempat dan lingkungan sekitar objek wisata. Media promosi obyek wisata berbasis E- Katalog sangat dibutuhkan guna mengatasi masalah-masalah tersebut.

E-Katalog adalah sebuah media eletronik yang di buat dengan maksud memberikan informasi sekaligus promosi secara efektif dalam layout menarik serta menyajikan informasi yang lebih mendetail dari media lainnya [2]. Menurut [3] bahwa E-Katalog pariwisata dengan informasi spesifik yang mencakup komponen produk pariwisata di sebuah kawasan wisata dapat memfasilitasi masyarakat dalam memperkenalkan destinasi wisata ke ranah internasional melalui media sosial, web dan sebagainya.

Media promosi obyek wisata berbasis E- Katalog dapat mengvisualisasikan obyek wisata dalam bentuk album photo dan video dan peta objek wisata. EKatalog juga akan menampilan informasi seputar obyek wisata dan peta bagaimana cara menuju kesana.

Obyek wisata yang akan penulis maksukkan ke dalam E-Katalog ini hanya 4 obyek wisata. Mewakili satu tempat obyek wisata yang ada di MAMMINASATA. Obyek wisata yang dipilih merupakan obyek wisata yang ramai di datangi wisatawan, sehingga sangat penting untuk di promosikan. Adapun obyek wisata yang akan dimasukan ke dalam E-katalog adalah pulau kodingareng keke yang berada di Kota Makassar, Hutan karst rammang-rammang di Kabupaten Maros, Kebun wisata di Kabupaten Gowa, dan pantai punnaga di Kabupaten Takalar.

\section{METODE PENELITIAN}

Penelitian ini merupakan penelitan Research and Development (R\&D) yang telah dimodifikasi [4]. Pengembangan E-katalog objek wisata MAMMINASATA menggunkan model waterfall. 


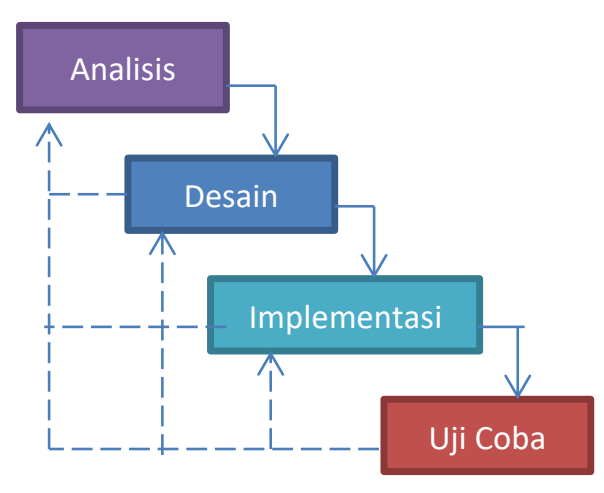

Gambar 1. Model pengembangan Waterfall

\section{Analisis Kebutuhan}

Tujuan dari analisis kebutuhan adalah memahami kebutuhan produk dan mengembangkan sebuah produk yang mewadahi kebutuhan tersebut. Analisis kebutuhan sistem digolongkan menjadi dua, yaitu kebutuhan fungsional (functional requirement) dan kebutuhan nonfungsional (nonfunctional requirement). Data-data analisis kebutuhan diperoleh dari observasi langsung dan studi pustaka. Informasi yang dikumpulkan meliputi: 1) Letak objek wisata; 2) Cara menuju objek wisata; 3) Fasilitas yang tersedia; 4) Estimasi Biaya.

Selanjutnya kebutuhan nonfungsional meliputi komputer dengan kapasitas; 1) processor core i3; 2) RAM 4 GB; 3) Hard Disk 500 GB. Software yang digunakan dalam aplikasi ini adalah macromedia flash dan photoshop.

\section{Desain}

Desain merupakan rancangan produk dari data hasil analisis kebutuhan fungsional yang diwujudkan dalam bentuk storyboard, gambar, dan bagan.

\section{a. Storyboard}

Storyboard dibuat untuk melihat bagian interface dari sistem yang akan dibuat. Pada bagian ini akan dimunculkan sketsa dari berbagai tampilan berdasarkan rancangan dan analisis kebutuhan yang telah dilakukan.

\section{b. Struktur Menu}

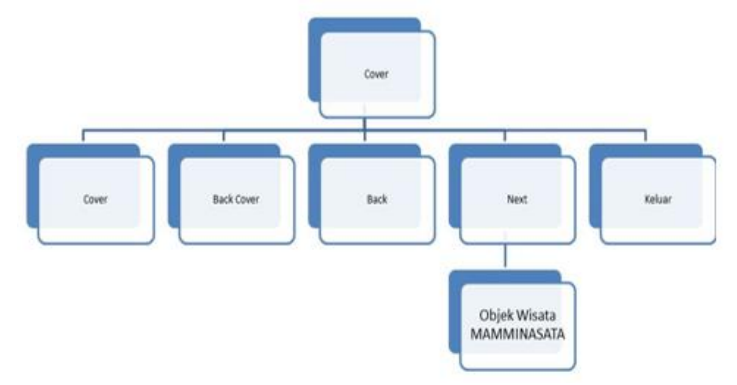

Gambar 2. Struktur Menu

\section{c. Perancangan Antar Muka}

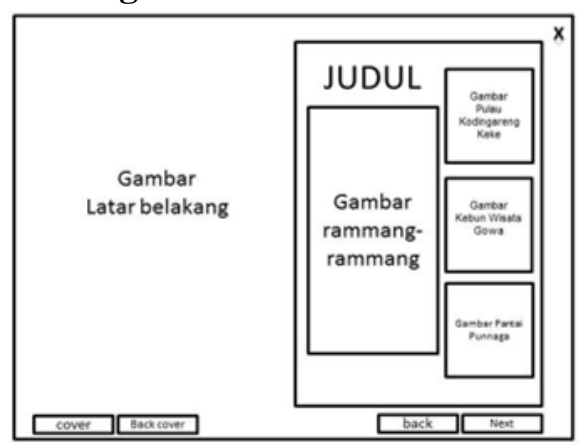

Gambar 3. Page Cover

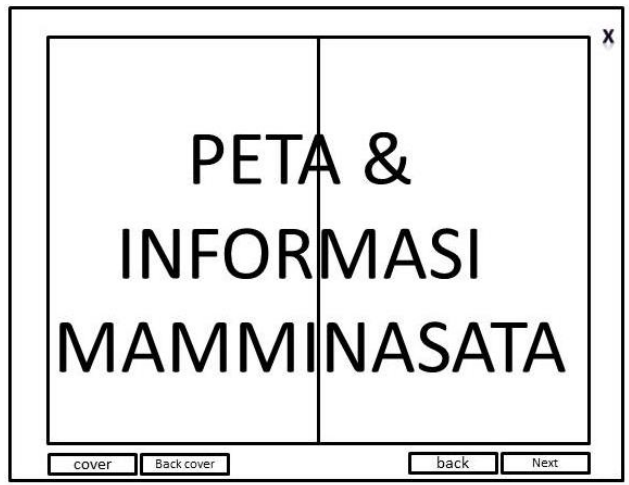

Gambar 4. Halaman 1 dan 2

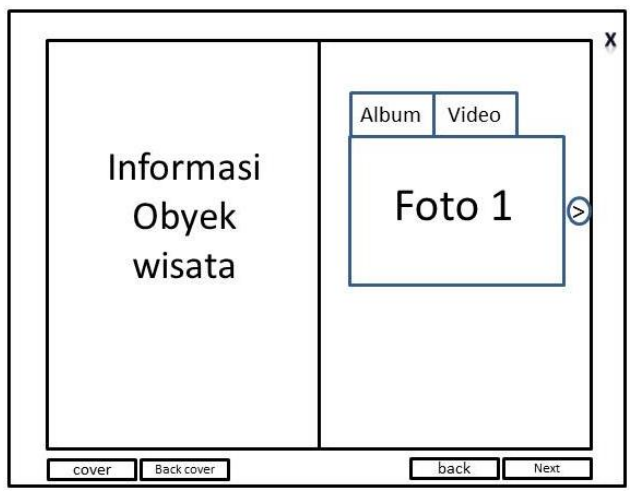

Gambar 5. Halaman 3 dan 4

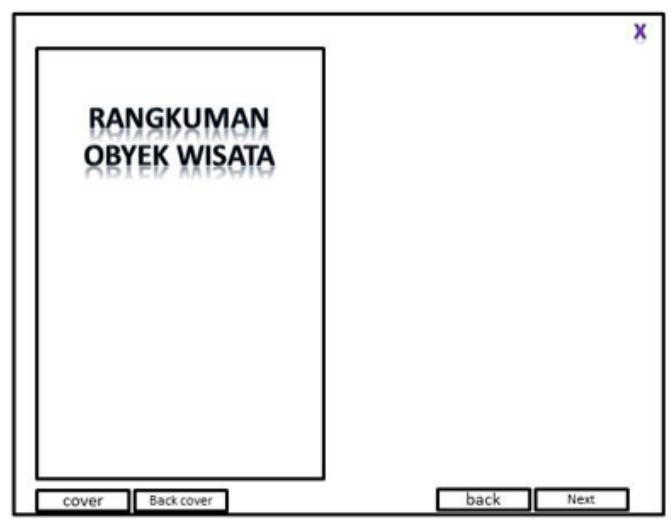

Gambar 6. Back Cover

\section{Implementasi}

Tahapan ini merupakan tahapan pembuatan produk berdasarkan hasil desain yang telah dibuat 


\section{Uji Coba}

Sebelum dilakukan uji coba produk terlebih dahulu di validasi oleh validator media sebanyak 2 orang. Uji coba dilakukan untuk mengetahui bagaimana tanggapan pengguna terhadap $E$ katalog.

Data dari angket dianalisis menggunakan teknik deskriptif persentase untuk melihat dengan rumus sebagai berikut [5]:

$$
P=\frac{f}{N} \times 100 \%
$$

Keterangan:

$\mathrm{P}=$ persentase skor

$\mathrm{F}=$ jumlah skor yang diperoleh

$\mathrm{N}=$ jumlah skor maksimum

Skor tertinggi angkat 5 dan skor terendah 1 , skor inilah yang akan di diberikan oleh validator media. Berikut cara menentukan kriteria validasi:

1) Menentukan persentase skor ideal (skor maksimum), yaitu (5:5) x 100\% $=100 \%$

2) Menentukan persentase skor terendah (skor minimum),yaitu $(1: 5) \times 100 \%=20 \%$

3) Menentukan range, yaitu $100 \%-20 \%=80 \%$

4) Kelas interval ada lima yaitu: (sangat layak, layak, kurang layak, tidak layak, dan sangant tidak layak)

5) Panjang interval, yaitu $80: 5=16 \%$

Ketetapan rentang persentase dan kriteria uji kelayakan media dapat ditetapkan sebagai berikut:

TABEL 1. RENTANG PERSENTASE DAN KRITERIA KUALITATIF UJI KELAYAKAN PRODUK.

\begin{tabular}{ll}
\hline Rentang Persentase & Kriteria Kualitatif \\
\hline $85 \%-100 \%$ & Sangat Baik \\
$69 \%-84 \%$ & Baik \\
$53 \%-68 \%$ & Kurang Baik \\
$37 \%-52 \%$ & Tidak Baik \\
$20 \%-36 \%$ & Sangat Tidak Baik \\
\hline
\end{tabular}

Sama halnya dengan validator, pengguna produk akan menjawab pertanyaan dengan memberi skor sesuai rubrik angket (skor tertinggi $=5$ dan skor terendah=1). Penentuan kriteria tanggapan pengguna ditentukan dengan cara sebagai berikut [6]:

TABEL 2. RENTANG PERSENTASE DAN KRITERIA KUALITATIF PRODUK

\begin{tabular}{ll}
\hline Rentang Persentase & Kriteria Kualitatif \\
\hline $85 \%-100 \%$ & Sangat Baik \\
$69 \%-84 \%$ & Baik \\
$53 \%-68 \%$ & Kurang Baik \\
$37 \%-52 \%$ & Tidak Baik \\
$20 \%-36 \%$ & Sangat Tidak Baik \\
\hline
\end{tabular}

\section{HASIL DAN PEMBAHASAN}

A. Hasil Perancangan

\section{Page Cover}

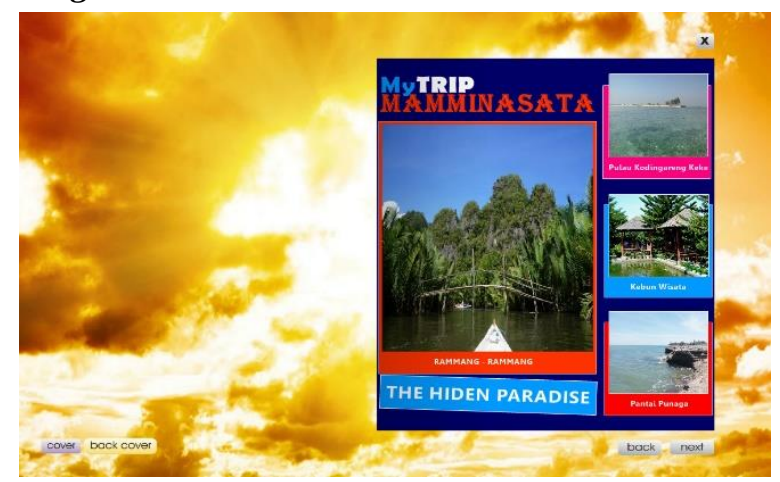

Gambar 7. Page Cover

\section{Page 1 dan 2}

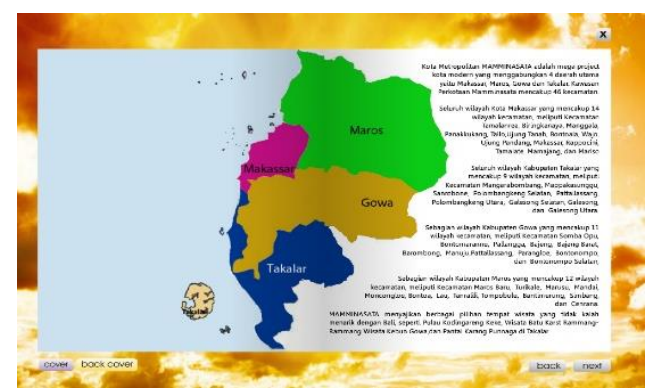

Gambar 8. Page 1 dan 2

\section{Page 3 dan 4}

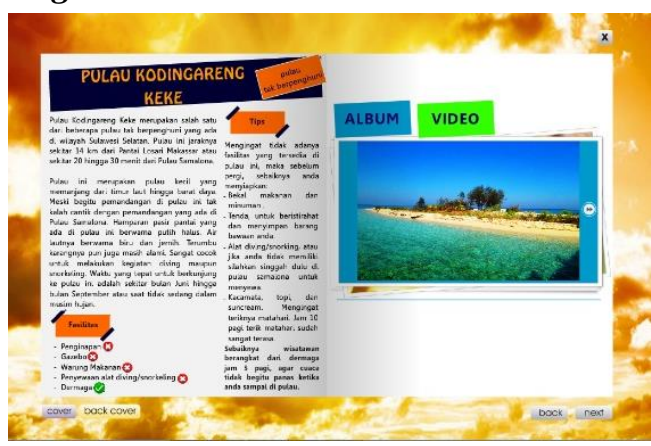

Gambar 9. Page 3 dan 4

\section{Page Album dan Video}

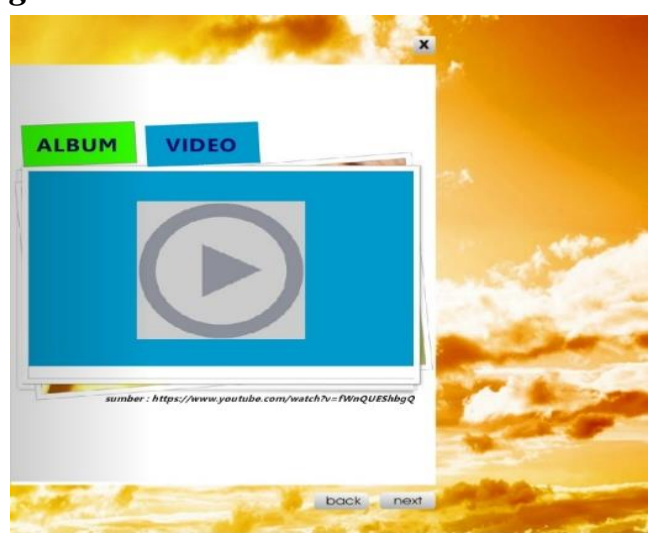

Gambar 10. Page Album dan Video 
5. Page 5 dan 6

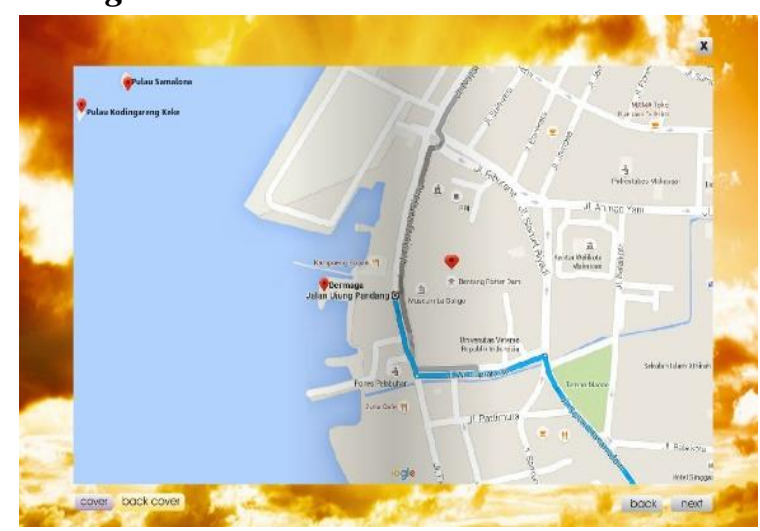

Gambar 11. Page 5 dan 6

\section{Page Back Cover}

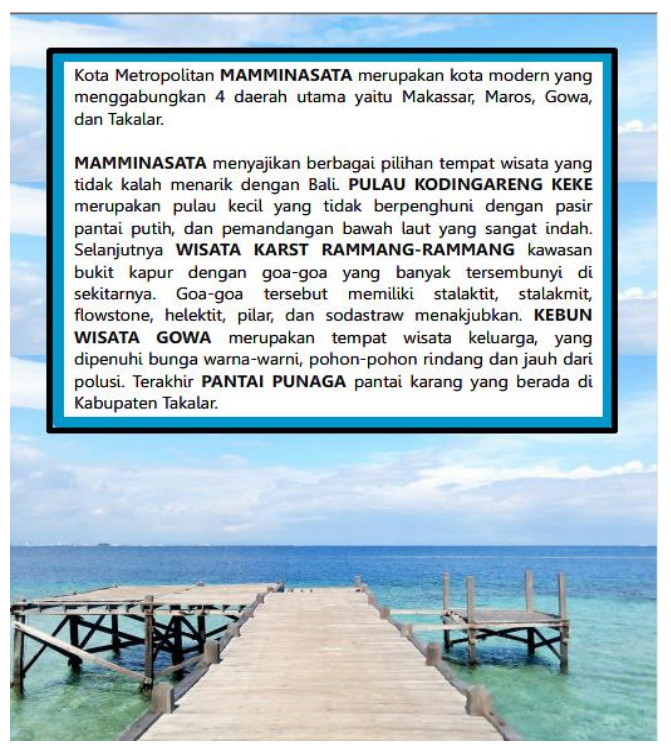

Gambar 12. Page Back Cover

\section{B. Hasil Uji Coba}

\section{Validasi Produk}

Hasil dari validasi Media Promosi E-Katalog Obyek Wisata MAMMINASATA ini bisa dilihat pada Tabel 3:

TABEL 3. HASIL VALIDASI PRODUK

\begin{tabular}{llll}
\hline No & Variabel & Persentase & Keterangan \\
\hline 1 & Efisiensi & $95 \%$ & Sangat Layak \\
2 & Tampilan & $91 \%$ & Sangat Layak \\
3 & Hasil Produk & $93 \%$ & Sangat Layak \\
\hline
\end{tabular}

Berdasarkan penilaian validator di atas dapat diartikan bahwa Efisiensi produk memiliki kategori sangat layak dengan persentase sebesar 95\%. Dari aspek tampilan hasil produk memiliki kategori sangat layak dengan persentase sebesar 91\%. Sedangkan aspek ketiga mengenai kualitas teknis dan keefektifan dinyatakan sangat layak dengan persentase sebesar 93\%. Sehingga secara keseluruhan produk Media Promosi E-Katalog Obyek Wisata MAMMINASATA Sangat Layak untuk digunakan dengan revisi.

\section{Uji Coba Produk}

Uji coba produk dilakukan oleh 7 orang Mahasiswa Pasca Sarjana dan 3 orang yang dipilih dari lingkungan tempat tinggal pengembang Media Promosi E-Katalog Obyek Wisata MAMMINASATA. Uji coba dilakukan guna mengetahui bagaimana tanggapan pengguna terhadap Media Promosi E-Katalog Obyek Wisata MAMMINASATA.

Berdasarkan hasil uji coba produk mengenai tanggapan pengguna terhadap tampilan media menarik rerata persentase sebesar 92\%. Hal ini menunjukkan bahwa tampilan media sangat baik.

Berdasarkan hasil uji coba produk mengenai kemudahan dalam penggunaan produk rerata persentase sebesar $86 \%$. Hal ini menunjukkan bahwa pengoperasian media sangat baik.

Persentase rerata untuk bahasa/perintah yang sederhana dan mudah dipahami sebesar $82 \%$, dan masuk dalam kategori baik. Selanjutnya mengenai informasi obyek wisata yang jelas dan tampilan album foto yang jelas sehingga pengguna tertatarik untuk datang berlibur persentase rerata sebesar $80 \%$, dan $92 \%$ masuk dalam kategori baik dan sangat baik.

Mengenai Tampilan video jelas dan menarik pengguna untuk datang berlibur persentase rerata sebesar $94 \%$, masuk dalam sangat baik. Sehingga dapat disimpulkan bahwa tanggapan pengguna mengenai Media Promosi E-Katalog Obyek Wisata MAMMINASATA sangat baik dengan persentase sebesar $88 \%$.

\section{KESIMPULAN}

E-Katalog Media Promosi Obyek Wisata MAMMINASATA dikembangkan melalui tahap analisis kebutuhan meliputi analisis kebutuhan fungsional dan nonfungsional, desain meliputi perancangan (story board, struktur menu dan perancangan antar muka), implementasi meliputi pembuatan produk dengan menggunakan macromedia flash 8, dan uji coba.

E-Katalog Media Promosi Obyek Wisata MAMMINASATA yang dikembangkan dinilai sangat layak oleh validator media dengan skor efisiensi produk memiliki kategori sangat layak dengan persentase sebesar 95\%. Dari aspek tampilan hasil produk memiliki kategori sangat layak dengan persentase sebesar 91\%. Sedangkan aspek ketiga mengenai kualitas teknis dan keefektifan dinyatakan sangat layak dengan persentase sebesar $93 \%$.

Tanggapan pengguna mengenai Media Promosi E-Katalog Obyek Wisata MAMMINASATA sangat baik dengan persentase sebesar $88 \%$. 


\section{DAFTAR PUSTAKA}

[1] Y. A. Ghani, "Pengembangan Sarana Prasarana Destinasi Pariwisata Berbasis Budaya di Jawa Barat," Jurnal Pariwisata, vol. 4, no. 1, pp. 22-31, 2017.

[2] H. A. REVIL HUDRIANI and M. S. D. Ariusmedi, "Perancangan Katalog Panduan Wisata Seribu Rumah Gadang Di Kabupaten Solok Selatan," DEKAVE: Jurnal Desain Komunikasi Visual, vol. 8, no. 3, 2019.

[3] A. T. Rumiati, J. Gunawan, and N. Ekasari, "Developing Indicators To Measure Sustainable Marine Tourism Development Study Case: In Selong Belanak Village, West Praya, Central Lombok Province," 2019.

[4] I. Sommerville, "Software engineering 9th Edition," ISBN-10, vol. 137035152, p. 18, 2011.

[5] A. Sudjiono, "Pengantar Statiska Pendidikan," Bandung: Rajawali Pers, 2008.

[6] N. Sudjana, "Metode statistika," Bandung: Tarsito, vol. 168, 2005.

[7] T. N. Sari, "Analisis kualitas dan pengembangan sistem informasi akademik berbasis web menggunakan standard iso 9126," JIKO (Jurnal Informatika dan Komputer), vol. 1, no. 1, 2016. 